\title{
A Comparative Electrochemical-Ozone Treatment for Removal of Phenolphthalein
}

\author{
V. M. García-Orozco, ${ }^{1}$ C. E. Barrera-Díaz, ${ }^{2}$ \\ G. Roa-Morales, ${ }^{2}$ and Ivonne Linares-Hernández ${ }^{3}$ \\ ${ }^{1}$ Facultad de Química, Universidad Autónoma del Estado de México, Paseo Colón, Intersección Paseo Tollocan S/N, \\ 50120 Toluca, MEX, Mexico \\ ${ }^{2}$ Centro Conjunto de Investigación en Química Sustentable UAEM-UNAM, Carretera Toluca-Atlacomulco, \\ Km 14.5, Campus San Cayetano, 50200 Toluca, MEX, Mexico \\ ${ }^{3}$ Centro Interamericano de Recursos del Agua, Universidad Autónoma del Estado de México, C.P. 50091 Toluca, MEX, Mexico \\ Correspondence should be addressed to C. E. Barrera-Díaz; cbd0044@gmail.com
}

Received 15 July 2016; Revised 15 September 2016; Accepted 21 September 2016

Academic Editor: Julie J. M. Mesa

Copyright ( 2016 V. M. García-Orozco et al. This is an open access article distributed under the Creative Commons Attribution License, which permits unrestricted use, distribution, and reproduction in any medium, provided the original work is properly cited.

The degradation of aqueous solutions containing phenolphthalein was carried out using ozone and electrochemical processes; the two different treatments were performed for $60 \mathrm{~min}$ at $\mathrm{pH} 3, \mathrm{pH} 7$, and $\mathrm{pH}$ 9. The electrochemical oxidation using boron-doped diamond electrodes processes was carried out using three current density values: $3.11 \mathrm{~mA} \cdot \mathrm{cm}^{-2}, 6.22 \mathrm{~mA} \cdot \mathrm{cm}^{-2}$, and $9.33 \mathrm{~mA} \cdot \mathrm{cm}^{-2}$, whereas the ozone dose was constantly supplied at $5 \pm 0.5 \mathrm{mgL}^{-1}$. An optimal degradation condition for the ozonation treatment is at alkaline $\mathrm{pH}$, while the electrochemical treatment works better at acidic $\mathrm{pH}$. The electrochemical process is twice better compared with ozonation.

\section{Introduction}

Water is one of the most valuable assets for a country; indeed, safe drinking water is a basic human right. Safe and reliable drinking water is vital to every community since human health has become expensive since inadequate water quality reduces work productivity $[1,2]$. Water scarcity is an economic threat for developing countries in which a large amount is used in agricultural, industrial, and domestic purposes [3].

Wastewater treatment has become a priority since good quality treated wastewater can be reused in some activities. An effective approach for treating wastewater is to carry out treatments in well-located sources. In this sense, water and wastewater testing laboratories generate large amounts of residues. In particular, the analysis and test for alkalinity and acidity using phenolphthalein ( $\mathrm{PHPH}$ ) produce large amounts of wastewater containing PHPH. In industrial operations such as the flavour drinking water industry, the mixing reactors in which the water is prepared should be cleaned after the process; this is commonly done using an aqueous solution containing $\mathrm{NaOH}$, and then rinsing water containing PHPH is used for checking that all $\mathrm{NaOH}$ has been eliminated.

PHPH was discovered by the German chemist Adolf von Baeyer in 1871. He prepared it by the fusion of phenol and phthalic anhydride in the presence of sulfuric acid or Zinc chloride $[4,5]$.

PHPH (1\%) is used in alcoholic solutions in titration as a $\mathrm{pH}$ visual indicator to unveil information regarding other compounds that include some organic and mineral acids as well as most alkalis. When working as an indicator, it turns pink in basic solutions usually above $\mathrm{pH} 10$ and colorless in acidic ones below pH 8 [6]. Furthermore, it is utilized to forecast depth of concrete carbonation. A different application for $\mathrm{PHPH}$ is in determination of diluted blood used for forensic evidences such as Kastle-Meyer test. Here, the color turns pink if the specimen analyzed contains haemoglobin. Likewise, PHPH is used as the staple ingredient to make disappearing dye in some toys [7]. $\mathrm{PHPH}$ can 
be traced in an assortment of ingested products and in some scientific applications too. Furthermore, it could be incorporated in tablets, powders, and liquids because of its odourless and tasteless features. Additionally, it is employed as a laxative, in the form of a gum laxative product or chocolate [8]. In 1999 [9], PHPH was removed from Overthe-Counter medication (OTC) laxatives by the Food and Drug Administration (FDA). Recently, PHPH test indicates that it could cause neoplasia and ovary cancer [10-12].

The use of advanced oxidation processes (AOPs) allows producing hydroxyl radicals, which are strong oxidant agents, ready to react with organics [13-16]. Unlike many other radicals, hydroxyl radicals are nonselective and thus readily attack a big group of organic chemicals to transform them into less complex and damaging intermediate products that can degrade in an indiscriminate way of micropollutants [17]; these ones possess reaction rate constants around $10^{9} \mathrm{Lmol}^{-1} \mathrm{~s}^{-1}[18]$.

Among others, electrooxidation and ozonation can produce hydroxyl radicals. Until now there are few studies in which both processes are used at the same time; indeed, PHPH degradation has not previously been reported.

\section{Materials and Methods}

2.1. Chemicals. Distilled water was used for the preparation of aqueous solutions, used as synthetic water prepared with PHPH (Técnical Química) at $5 \mathrm{mg} / \mathrm{L}$. $\mathrm{Na}_{2} \mathrm{SO}_{4}$ (Fermont) at $0.05 \mathrm{M}$ was selected as the support electrolyte in this work. The electrolytic medium was made basic, neutral, and acidic as required by the addition of aqueous $\mathrm{B}(\mathrm{OH})_{3}$ (J. T. Baker at $0,04 \mathrm{M}), \mathrm{H}_{3} \mathrm{PO}_{4}$ (Merck at 0,04 ), and $\mathrm{H}_{2} \mathrm{SO}_{4}$ (Fermont at $1 \mathrm{M})$, where $\mathrm{B}(\mathrm{OH})_{3}$ and $\mathrm{H}_{3} \mathrm{PO}_{4}$ (Merck) were used as buffer for maintaining the $\mathrm{pH}$ of 9 and 7 with the addition of $\mathrm{NaOH}$ (Merck at $5 \mathrm{M}$ ), respectively.

2.2. Electrooxidation Treatment. For this process a batch type reactor with cylindrical shape containing electrodes of boron-doped diamond (BDD) was used, where the electrodes were connected in parallel and each electrode is $20.6 \mathrm{~cm}$ large per $2.6 \mathrm{~cm}$ wide. Three electrodes were used as anodes and two as cathodes. The total anodic surface (Aa) was $321.36 \mathrm{~cm}^{2}$. While the capacity of the reactor was $1.2 \mathrm{~L}, 1.0 \mathrm{~L}$ was used at all experiments. $1-3 \mathrm{~A}\left(3.11,6.22\right.$, and $\left.9.33 \mathrm{~mA} \cdot \mathrm{cm}^{-2}\right)$ were supplied during all the process. Three different $\mathrm{pH}$ values were studied 3,7 , and 9 . Aliquots were taken at different elapsed times (Figure 1(a)).

2.3. Ozonation Treatment. In this treatment ozone was supplied by a Pacific Ozone Technology generator number LAB212 with Serial Number 7646; ozone was produced using dry air. The reactor is $40 \mathrm{~cm}$ long and $8 \mathrm{~cm}$ in diameter, and one liter of contaminated solution was used for the test. The reactor was fed, with ozone, in the bottom part through a porous plate, with a constant concentration of $5 \pm 0.5 \mathrm{mgL}^{-1}$. Ozonation experiments were carried out at the $\mathrm{pH}$ of 3,7 , and 9 , and samples were taken at regular intervals to determine the chemical oxygen demand (COD).
Ozone not used in the reaction was collected in the upper part of the reactor and directed to a heated catalytic ozone destruct, PACIFIC OZONE, Model Number d42202, with Serial Number 1687 (Figure 1(b)).

2.4. Analytic Methods. The aliquots were characterized before and after the treatment. In this characterization, COD was measured in accordance with APHA/AWWA/WPCE.

The concentration of total organic carbon (TOC) of each sample was measured in a Shimadzu Total Organic Carbon Analyzer (model $L_{\mathrm{CPH}}$ ) fitted with an autosampler [19].

The removal efficiency or percentage of COD removal (\%RE) was then calculated as follows [20]:

$$
\% \mathrm{RE}=\frac{\mathrm{COD}_{0}-\mathrm{COD}_{t}}{\mathrm{COD}_{0}} \times 100 \% .
$$

The instantaneous current efficiency (ICE) can be used to calculate the apparent Faradic efficiency of COD removal by using the following formula [21]:

$$
\mathrm{ICE}=\frac{\left[(\mathrm{COD})_{t}-(\mathrm{COD})_{t+\Delta t}\right] F * V * 100}{8 I \Delta t} .
$$

The energy consumption $\left(E_{C 1}\right)$ per unit COD mass (KWh mg ${ }^{-1}$ COD) was calculated using [22]

$$
E_{C 1}=\frac{I U t}{\left[(\mathrm{COD})_{t}-(\mathrm{COD})_{t+\Delta t}\right] V} ;
$$

then $(\mathrm{COD})_{t}$ and $(\mathrm{COD})_{t+\Delta t}$ are the COD values $\left(\mathrm{gO}_{2} \cdot \mathrm{dm}^{-3}\right)$ at $t$ and $t+\Delta t(\mathrm{~s})$, respectively, $I$ is the current intensity (A), $F$ is the Faraday constant $\left(96487 \mathrm{Cmol}^{-1}\right), V$ is the electrolyte solution volume $(\mathrm{L})$, the constant 8 is the oxygen equivalent mass (g eq. ${ }^{-1}$ ), and $U$ is the average cell voltage $(\mathrm{V})$.

Converting $\mathrm{m}^{3}$ to $\mathrm{dm}^{3}$ considering $1000 \mathrm{dm}^{3}$ equals $1 \mathrm{~m}^{3}$ and taking into account that the cost of electricity in US is $\$ 0.15$ (U.S. currency) per $\mathrm{kWh}$, the monetary value required to demean a unit of volume effluent is given by the equation below [23]:

$$
\begin{aligned}
\operatorname{Cost}\left(\mathrm{US}_{\mathrm{dm}}^{-3}\right)= & \mathrm{EC}\left(\mathrm{kWh} \mathrm{dm}^{-3}\right) \\
& \times 0.15(\mathrm{US} \$ / \mathrm{kWh}) .
\end{aligned}
$$

\section{Results and Discussions}

3.1. UV-Vis Characterization. Figure 2(a) shows the ultraviolet-visible spectroscopy (UV-Vis) absorption spectra,

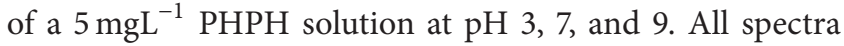
present two absorption bands. At $\mathrm{pH} 3$ and 7, however, they have an absorbance maximum in the wavelength $(\lambda)$ of $229 \mathrm{~nm}$, unlike at $\mathrm{pH} 9$, where such a maximum is located in $234 \mathrm{~nm}$. This is related to the protonated structure of the $\mathrm{PHPH}$ and agrees with the species distribution diagram found as described in Figure 2(b) (pka of PHPH is 9.7 $[7,24,25])$; the second of the three spectra is in $274 \mathrm{~nm}$, which corresponds to the $100 \%$ of the acid specie at $\mathrm{pH} 3$ and 7. At $\mathrm{pH} 9$, a change in these bands is observed, because there are $84 \%$ of acidic species $\mathrm{PHPH}$ and $16 \%$ of basic 


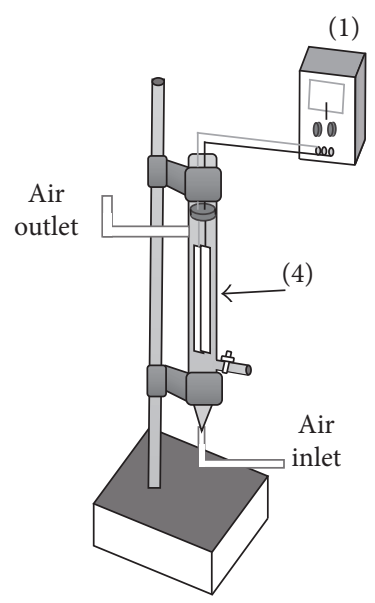
(1) DC power supply
(2) Ozone destroyer
(3) Ozone diffusor

(a)

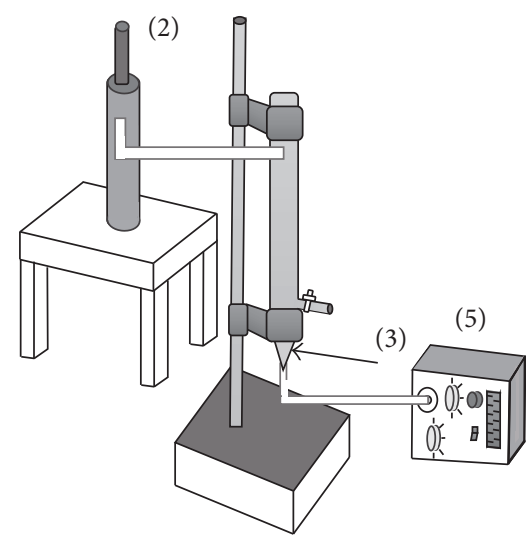

(4) BDD electrodes

(5) Ozone generator

(b)

Figure 1: Schematic diagram: (a) electrooxidation treatment; (b) ozonation treatment.

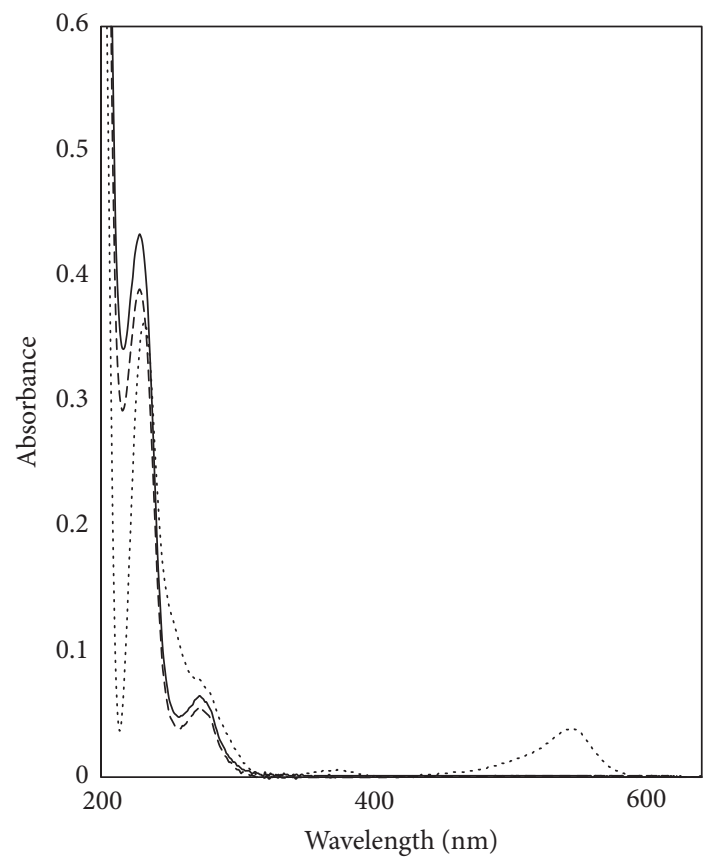

(a)

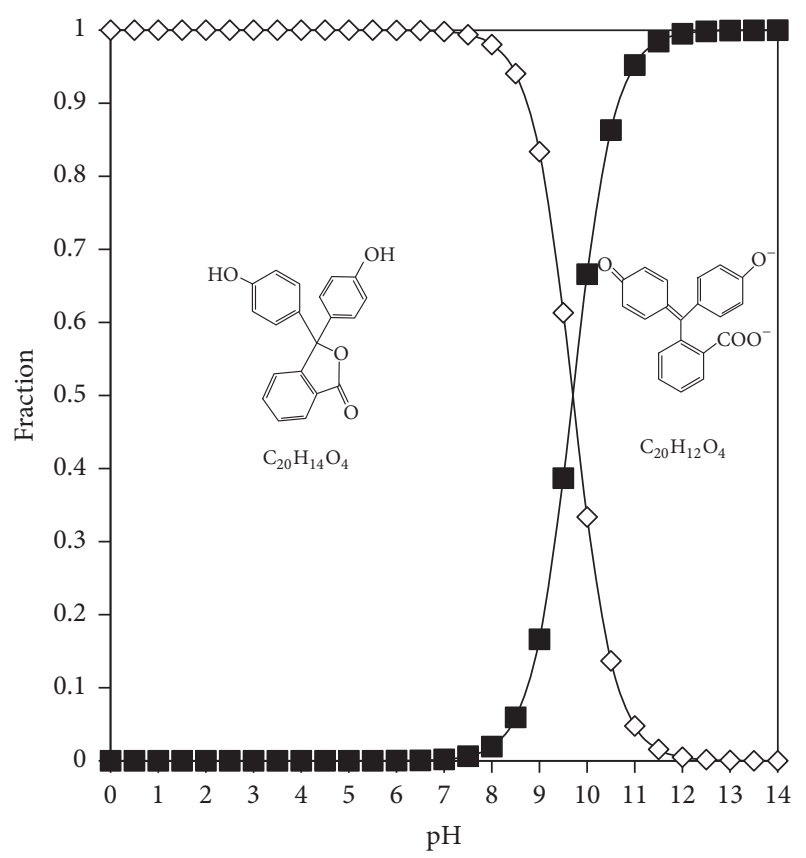

(b)

Figure 2: (a) UV-Vis PHPH peaks at different pH values: (...) 9, (-) 7, and (--) 3. (b) Chemical species distribution diagram, protonated and deprotonated: $(\diamond) \mathrm{C}_{20} \mathrm{H}_{14} \mathrm{O}_{4}$ and $(\boldsymbol{\square}) \mathrm{C}_{20} \mathrm{H}_{12} \mathrm{O}_{4}$.

species; additionally, an absorption band with an absorbance maximum of $554 \mathrm{~nm}$ is formed, which is associated with the pink color and is a consequence of the structure of the molecule formed in basic $\mathrm{pH}$.
3.2. Effect of Current Density in Electrooxidation Treatment. The effect of current densities $(J)\left(3.11 \mathrm{~mA} \cdot \mathrm{cm}^{-2}\right.$, $6.22 \mathrm{~mA} \cdot \mathrm{cm}^{-2}$, and $9.33 \mathrm{~mA} \cdot \mathrm{cm}^{-2}$ ) was studied to find the current density optimum value. 


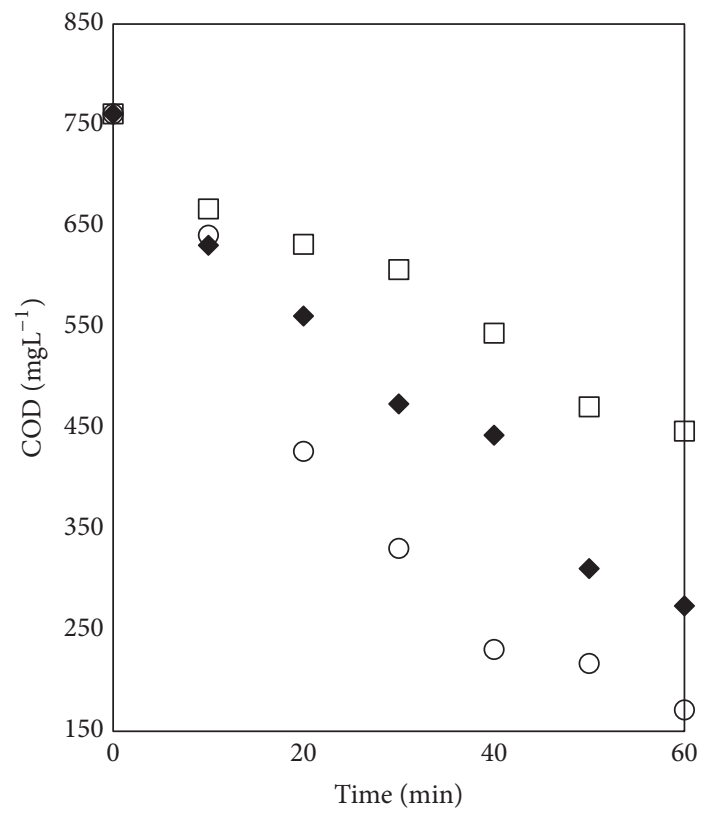

(a)

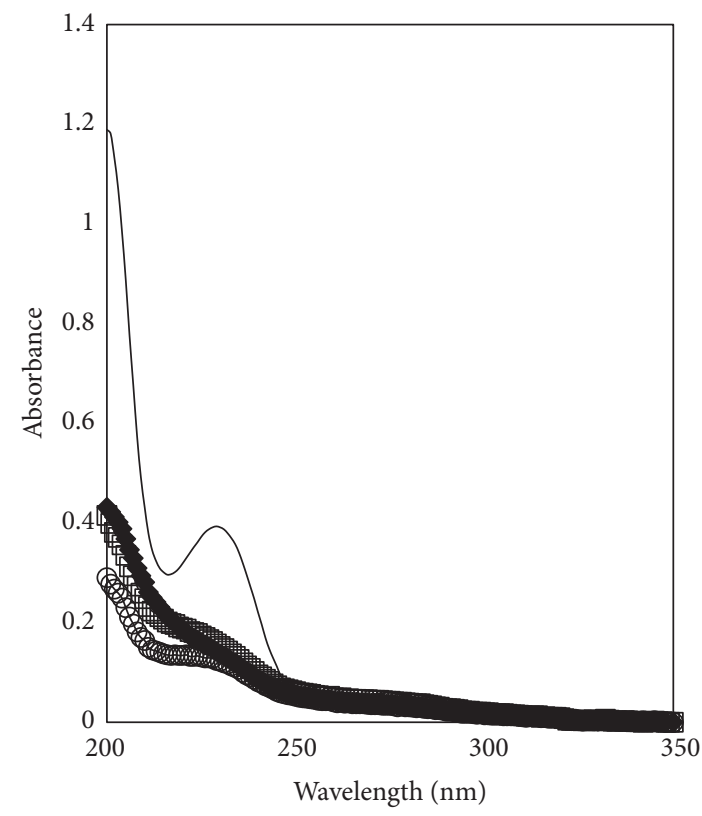

(b)

FIGURE 3: (a) Influence of the current density in the COD removal; (b) UV-Vis spectra: (a) PHPH solution in the electrooxidation treatment to $\mathrm{pH}(\square) 3.11,(\bullet) 6.22$, and (O) $9.33 \mathrm{~mA} \cdot \mathrm{cm}^{-2}$.

Figure 3(a) shows the removal of the PHPH using the COD; the process was performed at 60 minutes; taking aliquots every 10 minutes, the initial concentration of the PHPH was $5 \mathrm{mgL}^{-1}$, at $\mathrm{pH}$ 3. The current density that shows a greater removal of the COD is $9.33 \mathrm{~mA} \cdot \mathrm{cm}^{-2}$ obtaining a $71 \%$ COD decrease.

In previous reports the treatment time is associated with pollutant and color removal [26].

Figure 3(b) depicts the absorption spectra acquired during the treatment at the three current densities previously mentioned. This technique confirms how the PHPH is eliminating. The pollutant removal occurs by the hydroxyl radical reactions formed in the electrooxidation treatment. Hydroxyl radical $\left({ }^{\circ} \mathrm{OH}\right)$ formation occurs at the DDB surface [27]; its high oxidizing power oxidizes the organic material as shown in reaction (5) [28-31] and generates oxygen evolution. In this process it is possible to reach complete mineralization, where $\mathrm{CO}_{2}$ and $\mathrm{H}_{2} \mathrm{O}$ are formed according to Equations (6) and (7), and then $\mathrm{CO}_{2}$ can be hydrolyzed to form carbonate ions $[32,33]$.

$$
\begin{aligned}
\mathrm{BDD}+\mathrm{H}_{2} \mathrm{O} \longrightarrow & \mathrm{BDD}\left({ }^{\circ} \mathrm{OH}\right)+\mathrm{H}^{+}+\mathrm{e}^{-} \\
\mathrm{BDD}\left({ }^{\circ} \mathrm{OH}\right)+\mathrm{PHPH} \longrightarrow & \mathrm{BDD}+m \mathrm{CO}_{2}+n \mathrm{H}_{2} \mathrm{O} \\
\mathrm{BDD}\left({ }^{\circ} \mathrm{OH}\right)+\mathrm{PHPH} \longrightarrow & \mathrm{BDD} \\
& + \text { Mineralization products } \\
& +\mathrm{H}^{+}+\mathrm{e}^{-}
\end{aligned}
$$

Reactions (6) and (7) compete with the secondary reaction of hydroxyl radical transformation to $\mathrm{O}_{2}$ without any
TABLE 1: Energy consumption to amperages and different $\mathrm{pH}$.

\begin{tabular}{lccc}
\hline $\mathrm{pH}$ & $\mathrm{i}, \mathrm{A}$ & $\mathrm{Kwh} \mathrm{dm}^{-3}$ & ${\mathrm{US} \$ \mathrm{~m}^{-3}}^{-}$ \\
\hline 3 & 1 & 0.005 & 0.8 \\
3 & 2 & 0.013 & 2.0 \\
3 & 3 & 0.023 & 3.4 \\
7 & 2 & 0.014 & 2.0 \\
9 & 2 & 0.011 & 1.8 \\
\hline
\end{tabular}

participation of the anode surface as indicated in the following equation [34]:

$$
\mathrm{BDD}\left({ }^{\circ} \mathrm{OH}\right) \longrightarrow \mathrm{BDD}+\frac{1}{2} \mathrm{O}_{2}+\mathrm{H}^{+}+\mathrm{e}^{-}
$$

The energy consumption is shown in Table 1.

The optimal conditions for the electrooxidation treatment are presented in Figure 4(a); as shown, the acidic $\mathrm{pH}$ is more effective. The spectrum change after the treatment, as illustrated in Figure 4(b), which shows that the greater COD decreases is at $\mathrm{pH} 3$. It can be concluded that the optimal conditions are a current density of $6.22 \mathrm{~mA} \cdot \mathrm{cm}^{-2}$ and using $\mathrm{pH}$ of 3 .

Figure 5 shows the efficiency of the instantaneous current during the treatment of $6.22 \mathrm{~mA} \cdot \mathrm{cm}^{-2}$, which also shows the lowest ICE $(80 \%)$. This value indicates that almost all the energy is used in the degradation and there is little lost energy; this result agrees with previous works [35].

The better ICE percentage is found at the beginning stage of electrooxidation and it may be attributed to the presence of higher concentration of organics in the vicinity of the electrodes. This indicates that the electrooxidation is 


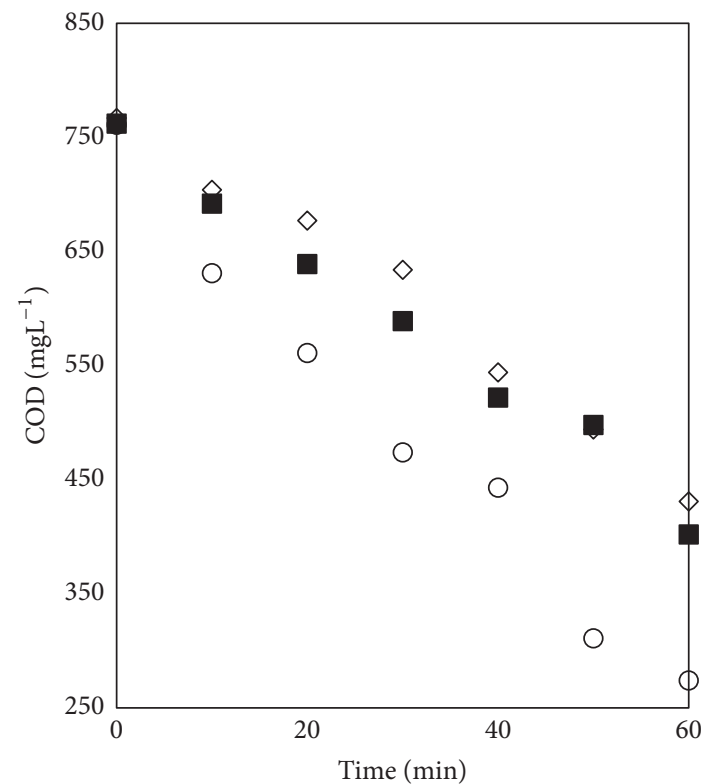

(a)

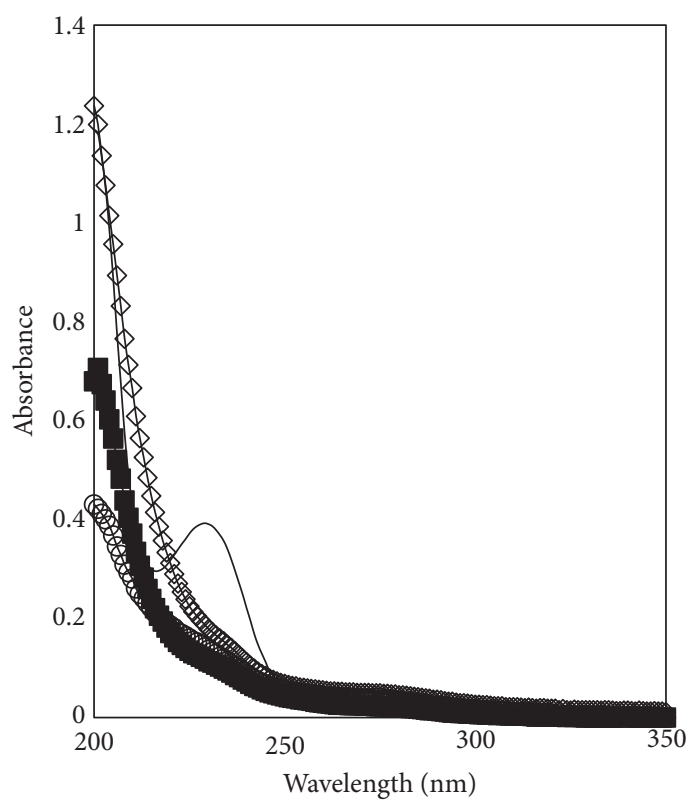

(b)

FIgURE 4: (a) Influence of the COD removal; (b) UV-Vis spectra: and $(\mathrm{O}) 3$.

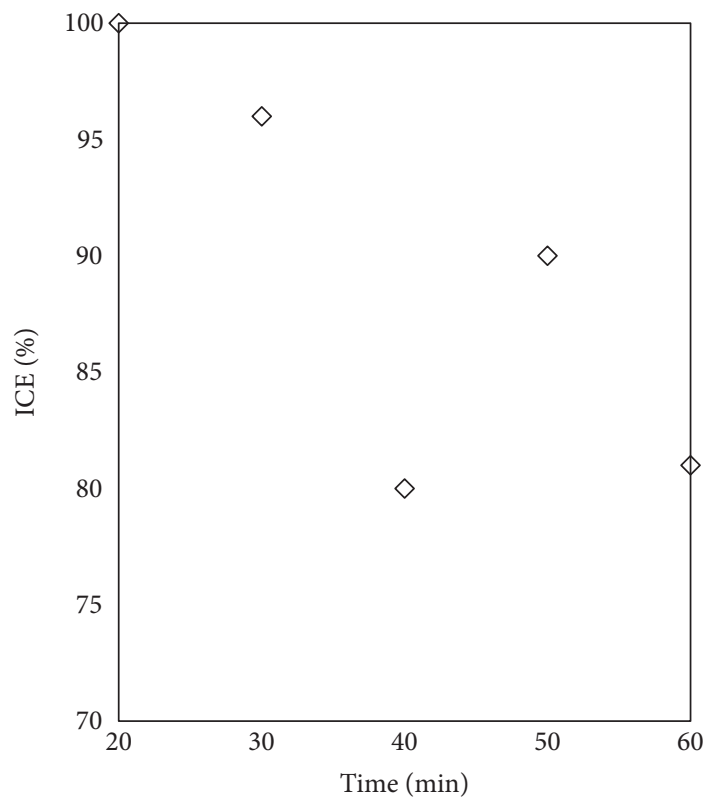

FIgURE 5: Instant Current Efficiency in the electrooxidation treatment to $(\diamond)$ using a current density of $6.22 \mathrm{~mA} \cdot \mathrm{cm}^{-2}$.

under current control regime at least in the middle stage of electrooxidation. It was observed that ICE decreased during the electrooxidation process. This may be explained due to the depletion of organics concentration in the vicinity of electrode surface [36].

3.3. Ozonation Treatment. The ozone was generated by an ozone generator (Equation (9)); the presence of ozone in the system generates the radicals (Equation (10)) that carry out the oxidation of the PHPH [37, 38]. Ozone has an oxidation potential of $2.07 \mathrm{v}[39,40]$. Figure 6(a) shows a $26 \%$ COD removal at $\mathrm{pH} 9$; in $\mathrm{pH} 7$ only $11 \%$ is reached, but at $\mathrm{pH} 3$ only $1 \%$ of the PHPH is removed after 60 minutes of treatment time. The main reactions (11)-(13) where hydroxyl radicals are formed are shown below: [41-44].

$$
\begin{gathered}
\mathrm{O}_{2}+\mathrm{O}^{\bullet} \leftrightarrows \mathrm{O}_{3} \\
\mathrm{O}^{\bullet}+\mathrm{H}^{+}+\mathrm{e}^{-} \longrightarrow{ }^{\circ} \mathrm{OH}
\end{gathered}
$$

The general stoichiometry occurs by the following equations, depending on whether the initiation is hydroxyl ions [41].

$$
3 \mathrm{O}_{3}+\mathrm{OH}^{-} \longrightarrow \mathrm{O}_{3}{ }^{-}+\mathrm{O}_{2}
$$

The hastened ozone decomposition resulted in the rapid production of $\mathrm{OH}^{*}$, leading to the higher removal of $\mathrm{PHPH}$ [43].

$$
\begin{gathered}
\mathrm{O}_{3}+\mathrm{OH}^{-} \longrightarrow \mathrm{HO}_{2}^{-}+\mathrm{O}_{2} \\
\mathrm{O}_{3}+\mathrm{HO}_{2}^{-} \rightleftarrows{ }^{-} \mathrm{OH}+\mathrm{O}_{2}{ }^{--}+\mathrm{O}_{2}
\end{gathered}
$$

We present reactions that occur during the ozonation process in Equations (9)-(13); this indicates that fragmentation of the molecule PHPH is taking place and not a degradation.

3.4. TOC Removal Comparison between Electrooxidation and Ozone Treatment. In Figure 7 the TOC removal as a function of treatment time is shown, the removal is higher by using the electrooxidation treatment, and in the case of ozonation the removal is lower by 50 percent with respect to TOC. 


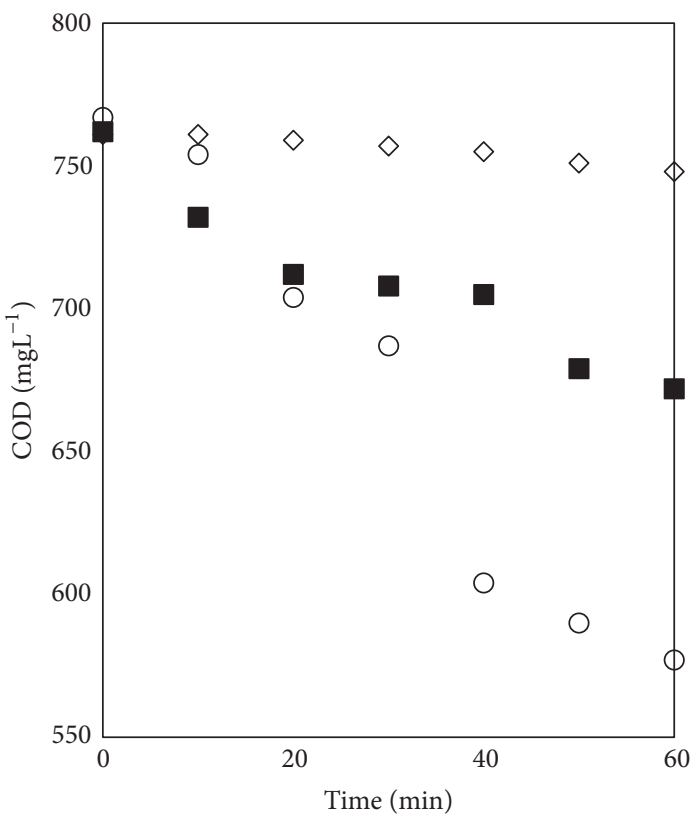

(a)

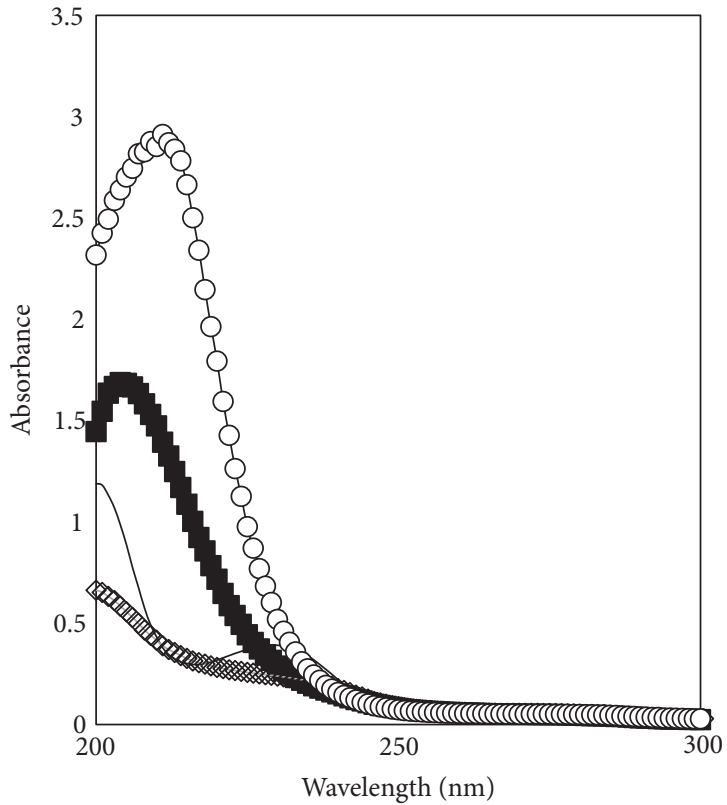

(b)

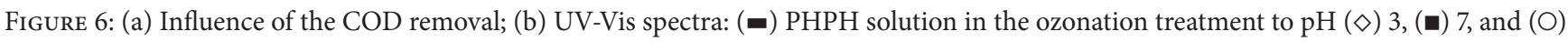
9.

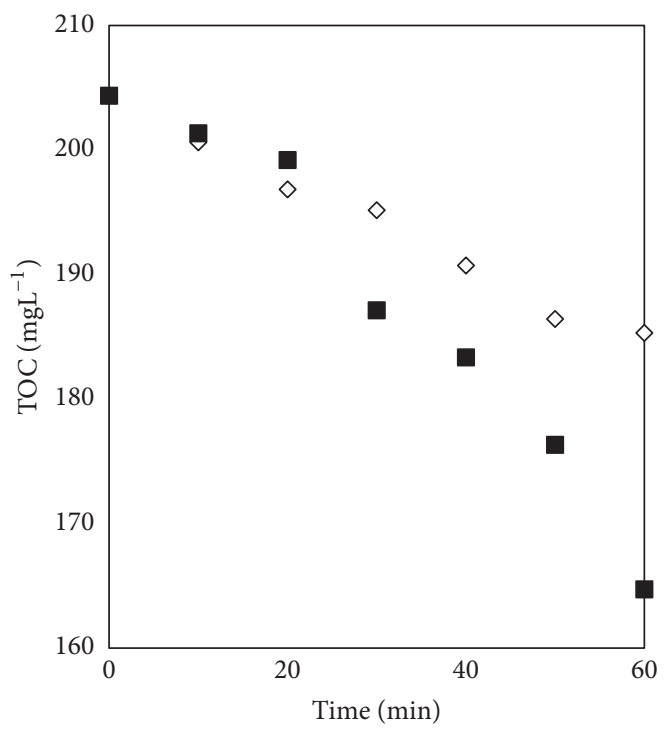

Figure 7: Influence of the TOC removal in the electrooxidation $(\boldsymbol{\square})$ and ozonation treatment $(\diamond)$.

In the first minutes, the results are similar in both methods because in the two methods hydroxyl radicals are available to attack the PHPH; however, the electrochemical treatment requires less steps to produce the radicals (since they are produced directly on the electrode surface), while the ozone requires more steps to produce the radicals and also is limited by the gas-liquid mass transfer phenomena.

3.5. Mechanism. The PHPH degradation mechanism is presented in Figure 8.

\section{Conclusions}

In this work we present two methods for the degradation of $\mathrm{PHPH}$ present in an aqueous solution. The electrochemical method requires acidic conditions to reach a $71 \%$ COD removal, whereas the ozone method requires basic conditions to obtain a $25 \%$ COD removal. This fact relies on the hydroxyl radicals production, which is faster in the electrochemical methods since less steps are required and a large anodic area provides a good mass transfer. The production of hydroxyl 


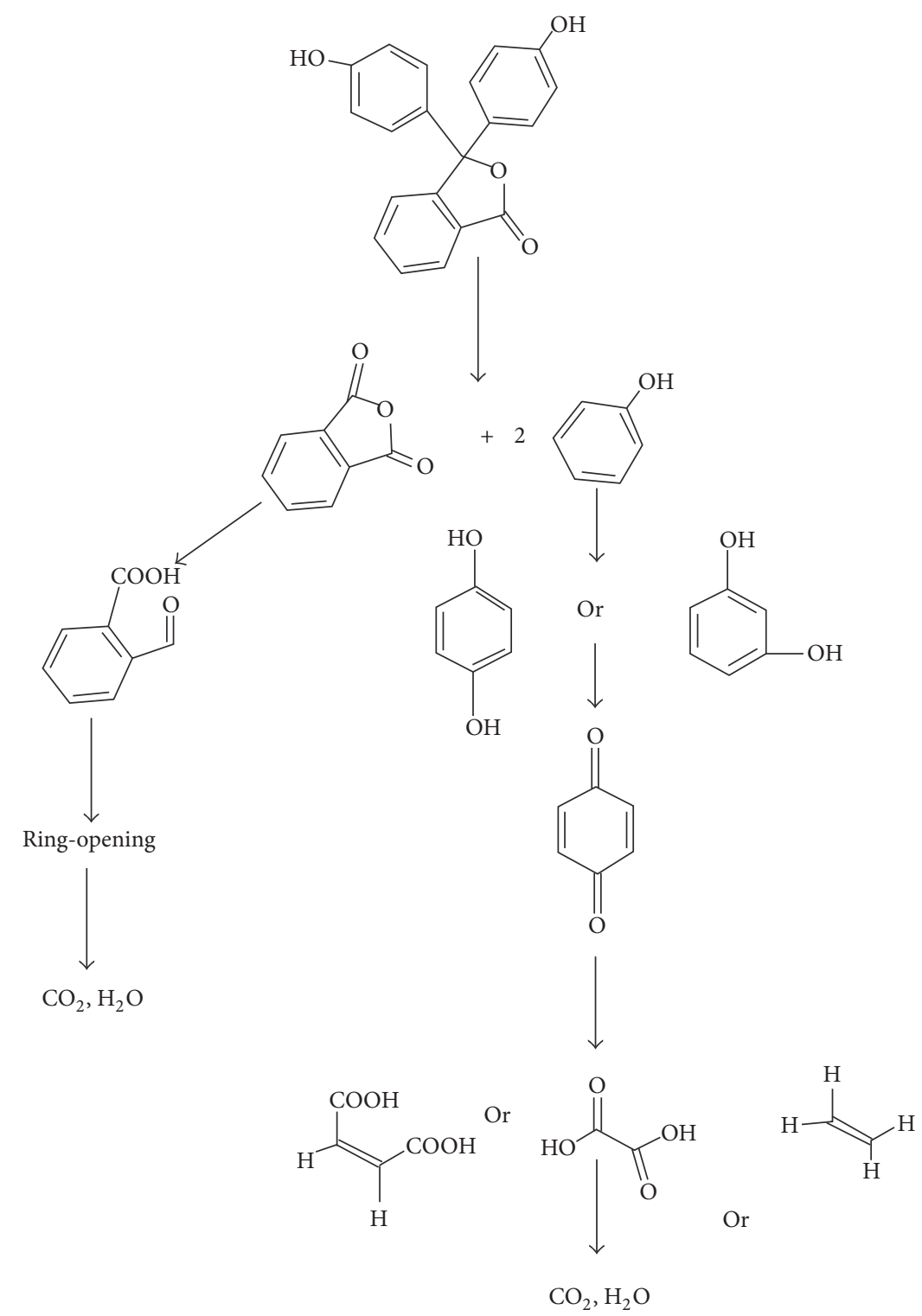

Figure 8: Proposed mechanism for the PHPH mineralization.

radicals using ozone involves more reactions and the mass transfer involves two phases: the gas and liquid.

\section{Competing Interests}

The authors declare that they have no competing interests.

\section{Acknowledgments}

The authors wish to acknowledge financial support from the CONACYT through the Project 153898, which is greatly appreciated.

\section{References}

[1] R. Mahanta, J. Chowdhury, and H. K. Nath, "Health costs of arsenic contamination of drinking water in Assam, India," Economic Analysis and Policy, vol. 49, pp. 30-42, 2016.
[2] A. Rasekh and K. Brumbelow, "A dynamic simulation-optimization model for adaptive management of urban water distribution system contamination threats," Applied Soft Computing Journal, vol. 32, pp. 59-71, 2015.

[3] B. Muchara, G. Ortmann, M. Mudhara, and E. Wale, "Irrigation water value for potato farmers in the Mooi River Irrigation Scheme of KwaZulu-Natal, South Africa: a residual value approach," Agricultural Water Management, vol. 164, pp. 243252, 2014.

[4] S. CTR, "Hoja De Datos De Seguridad Iloxan ${ }^{\circledR}, " 2014$, http:// www.ctr.com.mx/pdfcert/Fenolftaleina.pdf.

[5] B. J. F. MacFaddin, Pruebas Bioquímicas para la Identificación de Bacterias de Importancia Clínica, Edited by Tercera, Médica Panamericana S.A, Argentina, 2003.

[6] L. Liu, Y. Wang, D. Fan, and Y. Mi, "Using phenolphthalein as a promising indicator to monitor the vacuum freeze-drying process," Materials Letters, vol. 139, pp. 245-248, 2015. 
[7] S. Saeidnia and A. Manayi, "Phenolphthalein," Encyclopedia of Toxicology, vol. 3, pp. 877-880, 2014.

[8] G. Y. Çiftçi, M. Durmuş, E. Şenkuytu, and A. Kiliç, "Structural and fluorescence properties of phenolphthalein bridged cyclotriphosphazatrienes," Spectrochimica Acta Part A: Molecular and Biomolecular Spectroscopy, vol. 74, no. 4, pp. 881-886, 2009.

[9] IARC, Monograohs on the Evaluacion of Carcinogecic Risks to Humans. Carcinogenic Risks to Humans, vol. 76, International Agency for Research on Cancer, World Health Organization, 2000, http://monographs.iarc.fr/ENG/Monographs/ vol76/mono76-15.pdf.

[10] P. F. Coogan, L. Rosenberg, J. R. Palmer et al., "Phenolphthalein laxatives and risk of cancer," Journal of the National Cancer Institute, vol. 92, no. 23, pp. 1943-1944, 2000.

[11] G. S. Cooper, M. P. Longnecker, D. P. Sandler, and R. B. Ness, "Risk of ovarian cancer in relation to use of phenolphthaleincontaining laxatives," British Journal of Cancer, vol. 83, no. 3, pp. 404-406, 2000.

[12] J. R. Bucher, "Toxicology and carcinogenesis studies of in F344/ $\mathrm{N}$ rats and B6C3Fl mice (drinking water studies)," National Toxicology Program, no. 393, 1990.

[13] J. Brame, M. Long, Q. Li, and P. Alvarez, "Inhibitory effect of natural organic matter or other background constituents on photocatalytic advanced oxidation processes: mechanistic model development and validation," Water Research, vol. 84, pp. 362-371, 2015.

[14] M. Cheng, G. Zeng, D. Huang et al., "Hydroxyl radicals based advanced oxidation processes (AOPs) for remediation of soils contaminated with organic compounds: a review," Chemical Engineering Journal, vol. 284, pp. 582-598, 2016.

[15] S. O. Ganiyu, E. D. van Hullebusch, M. Cretin, G. Esposito, and M. A. Oturan, "Coupling of membrane filtration and advanced oxidation processes for removal of pharmaceutical residues: a critical review," Separation and Purification Technology, vol. 156, pp. 891-914, 2015.

[16] H. Suzuki, S. Araki, and H. Yamamoto, "Evaluation of advanced oxidation processes (AOP) using $\mathrm{O}_{3}, \mathrm{UV}$, and $\mathrm{TiO}_{2}$ for the degradation of phenol in water," Journal of Water Process Engineering, vol. 7, pp. 54-60, 2015.

[17] K. Ayoub, E. D. van Hullebusch, M. Cassir, and A. Bermond, "Application of advanced oxidation processes for TNT removal: a review," Journal of Hazardous Materials, vol. 178, no. 1-3, pp. 10-28, 2010.

[18] A. R. Ribeiro, O. C. Nunes, M. F. R. Pereira, and A. M. T. Silva, "An overview on the advanced oxidation processes applied for the treatment of water pollutants defined in the recently launched directive 2013/39/EU," Environment International, vol. 75, pp. 33-51, 2015.

[19] L. Hurtado, R. Natividad, E. Torres-García, J. Farias, and G. Li Puma, "Correlating the photocatalytic activity and the optical properties of LiVMoO6 photocatalyst under the UV and the visible region of the solar radiation spectrum," Chemical Engineering Journal, vol. 262, pp. 1284-1291, 2015.

[20] P. Aravind, V. Subramanyan, S. Ferro, and R. Gopalakrishnan, "Eco-friendly and facile integrated biological-cum-photo assisted electrooxidation process for degradation of textile wastewater," Water Research, vol. 93, pp. 230-241, 2016.

[21] S. Ellouze, M. Panizza, A. Barbucci, G. Cerisola, T. Mhiri, and S. C. Elaoud, "Ferulic acid treatment by electrochemical oxidation using a BDD anode," Journal of the Taiwan Institute of Chemical Engineers, vol. 59, pp. 132-137, 2016.
[22] N. Abdessamad, H. Akrout, G. Hamdaoui, K. Elghniji, M. Ksibi, and L. Bousselmi, "Evaluation of the efficiency of monopolar and bipolar BDD electrodes for electrochemical oxidation of anthraquinone textile synthetic effluent for reuse," Chemosphere, vol. 93, no. 7, pp. 1309-1316, 2013.

[23] A. J. C. da Silva, E. V. dos Santos, C. C. de Oliveira Morais, C. A. Martínez-Huitle, and S. S. L. Castro, "Electrochemical treatment of fresh, brine and saline produced water generated by petrochemical industry using $\mathrm{Ti} / \mathrm{IrO} 2-\mathrm{Ta} 2 \mathrm{O} 5$ and $\mathrm{BDD}$ in flow reactor," Chemical Engineering Journal, vol. 233, pp. 47-55, 2013.

[24] S. Islam, N. Bidin, S. Riaz, and S. Naseem, "Sol-gel based phenolphthalein encapsulated heterogeneous silica-titania optochemical pH nanosensor," Journal of Industrial and Engineering Chemistry, vol. 34, pp. 258-268, 2016.

[25] A. V. Kachur, A. A. Popov, E. J. Delikatny, J. S. Karp, and A. V. Popov, "Synthesis of ${ }^{18}$ F-labeled phenolphthalein and naphtholphthalein," Journal of Fluorine Chemistry, vol. 151, pp. 1-6, 2013.

[26] A. Thiam, I. Sirés, J. A. Garrido, R. M. Rodríguez, and E. Brillas, "Effect of anions on electrochemical degradation of azo dye Carmoisine (Acid Red 14) using a BDD anode and air-diffusion cathode," Separation and Purification Technology, vol. 140, pp. 43-52, 2015.

[27] C. Comninellis, Electrochemistry for the Environment, Primera, New York, NY, USA, Guohua Chen, Springer, London, USA, 2010.

[28] S. Garcia-Segura, Á. S. Lima, E. B. Cavalcanti, and E. Brillas, "Anodic oxidation, electro-Fenton and photoelectro-Fenton degradations of pyridinium- and imidazolium-based ionic liquids in waters using a BDD/air-diffusion cell," Electrochimica Acta, vol. 198, pp. 268-279, 2016.

[29] H. T. Madsen, E. G. Søgaard, and J. Muff, "Study of degradation intermediates formed during electrochemical oxidation of pesticide residue 2,6-dichlorobenzamide (BAM) at boron doped diamond (BDD) and platinum-iridium anodes," Chemosphere, vol. 109, pp. 84-91, 2014.

[30] I. Sirés, E. Brillas, G. Cerisola, and M. Panizza, "Comparative depollution of mecoprop aqueous solutions by electrochemical incineration using $\mathrm{BDD}$ and $\mathrm{PbO}_{2}$ as high oxidation power anodes," Journal of Electroanalytical Chemistry, vol. 613, no. 2, pp. 151-159, 2008.

[31] C. Zhang, Y. Jiang, Y. Li, Z. Hu, L. Zhou, and M. Zhou, “Threedimensional electrochemical process for wastewater treatment: a general review," Chemical Engineering Journal, vol. 228, pp. 455-467, 2013.

[32] M. A. García-Morales, G. Roa-Morales, C. Barrera-Díaz, B. Bilyeu, and M. A. Rodrigo, "Synergy of electrochemical oxidation using boron-doped diamond (BDD) electrodes and ozone $\left(\mathrm{O}_{3}\right)$ in industrial wastewater treatment," Electrochemistry Communications, vol. 27, pp. 34-37, 2013.

[33] S. A. Alves, T. C. R. Ferreira, N. S. Sabatini et al., "A comparative study of the electrochemical oxidation of the herbicide tebuthiuron using boron-doped diamond electrodes," Chemosphere, vol. 88, no. 2, pp. 155-160, 2012.

[34] I. Linares-Hernández, C. Barrera-Díaz, B. Bilyeu, P. JuárezGarcíaRojas, and E. Campos-Medina, "A combined electrocoagulation-electrooxidation treatment for industrial wastewater," Journal of Hazardous Materials, vol. 175, no. 1-3, pp. 688694, 2010.

[35] L. Yan, Y. Wang, J. Li et al., "Comparative study of different electrochemical methods for petroleum refinery wastewater treatment," Desalination, vol. 341, no. 1, pp. 87-93, 2014. 
[36] G. B. Raju, M. T. Karuppiah, S. S. Latha, S. Parvathy, and S. Prabhakar, "Treatment of wastewater from synthetic textile industry by electrocoagulation-electrooxidation," Chemical Engineering Journal, vol. 144, no. 1, pp. 51-58, 2008.

[37] C.-W. Kan, H.-F. Cheung, and Q. Chan, "A study of plasmainduced ozone treatment on the colour fading of dyed cotton," Journal of Cleaner Production, vol. 112, pp. 3514-3524, 2016.

[38] S. Khuntia, S. K. Majumder, and P. Ghosh, "Quantitative prediction of generation of hydroxyl radicals from ozone microbubbles," Chemical Engineering Research and Design, vol. 98, pp. 231-239, 2015.

[39] G. Chen, "Electrochemical technologies in wastewater treatment," Separation and Purification Technology, vol. 38, no. 1, pp. 11-41, 2004.

[40] W. Hanni, A. Perret, M. Blaschke et al., "Electrochemical advanced oxidation process for water treatment using DiaChem ${ }^{\circledR}$ electrodes," Diamond and Related Materials, vol. 11, no. 3-6, pp. 640-645, 2002.

[41] M. A. Alsheyab and A. H. Muñoz, "Reducing the formation of trihalomethanes (THMs) by ozone combined with hydrogen peroxide $\left(\mathrm{H}_{2} \mathrm{O}_{2} / \mathrm{O}_{3}\right)$," Desalination, vol. 194, no. 1-3, pp. 121-126, 2006.

[42] W. T. M. Audenaert, D. Vandierendonck, S. W. H. Van Hulle, and I. Nopens, "Comparison of ozone and $\mathrm{HO}^{\circ}$ radical dot induced conversion of effluent organic matter (EfOM) using ozonation and UV/ $\mathrm{H}_{2} \mathrm{O}_{2}$ treatment," Water Research, vol. 47, no. 7, pp. 2387-2398, 2013.

[43] Z. Chen, J. Fang, C. Fan, and C. Shang, "Oxidative degradation of N-Nitrosopyrrolidine by the ozone/UV process: kinetics and pathways," Chemosphere, vol. 150, pp. 731-739, 2016.

[44] H.-W. Chen, Y.-L. Kuo, C.-S. Chiou, S.-W. You, C.-M. Ma, and C.-T. Chang, "Mineralization of reactive Black 5 in aqueous solution by ozone $/ \mathrm{H}_{2} \mathrm{O}_{2}$ in the presence of a magnetic catalyst," Journal of Hazardous Materials, vol. 174, no. 1-3, pp. 795-800, 2010. 

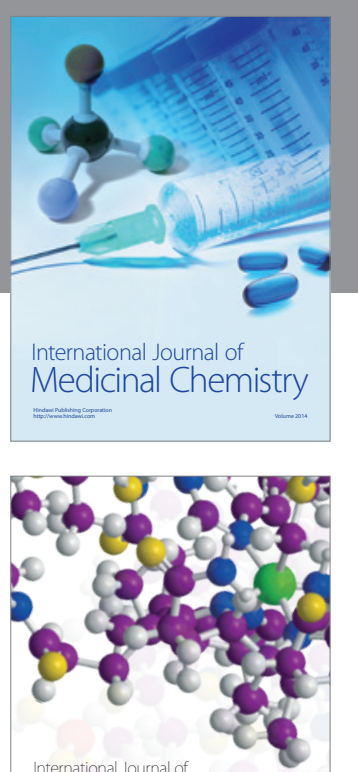

Carbohydrate Chemistry

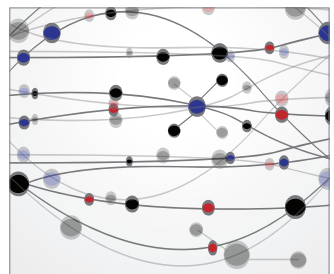

The Scientific World Journal
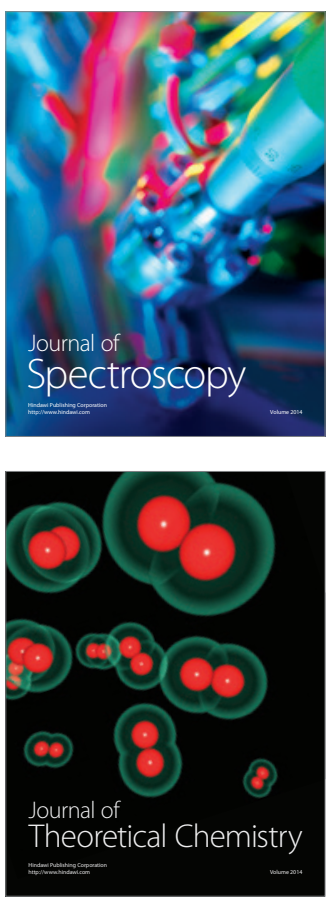
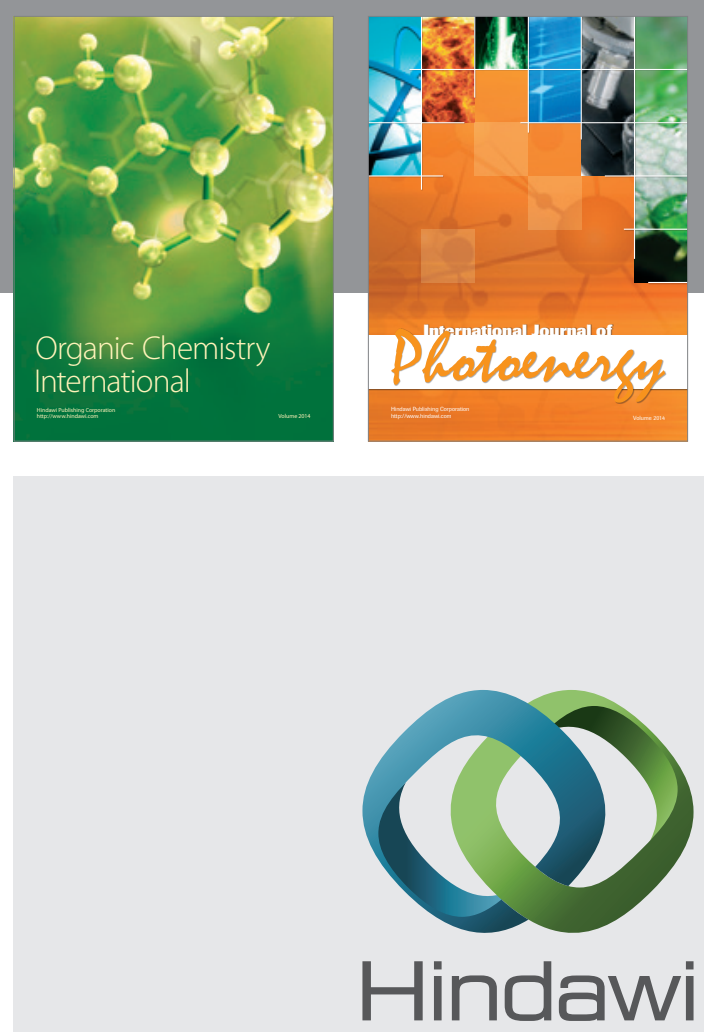

Submit your manuscripts at

http://www.hindawi.com

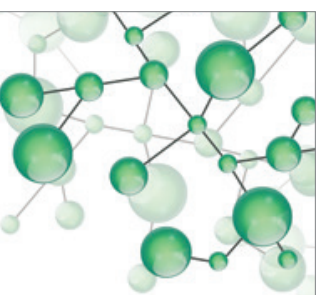

International Journal of

Inorganic Chemistry

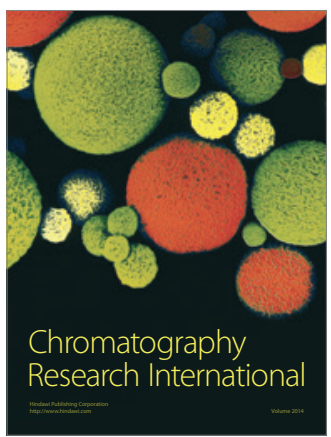

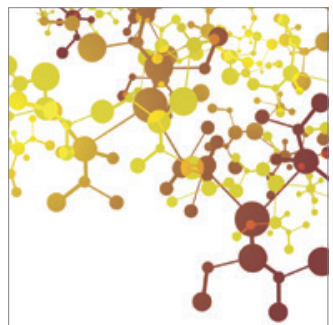

Applied Chemistry
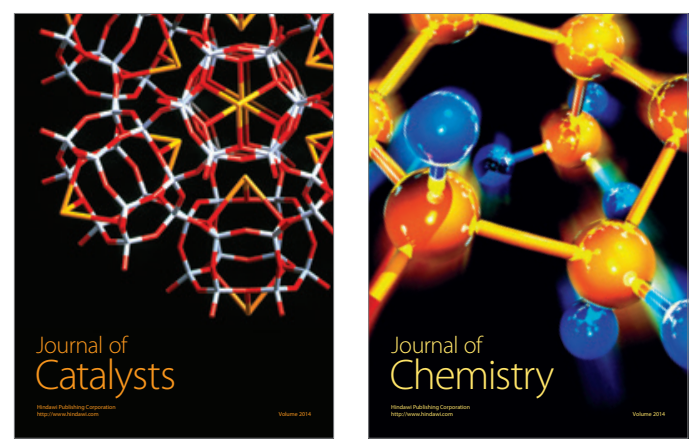
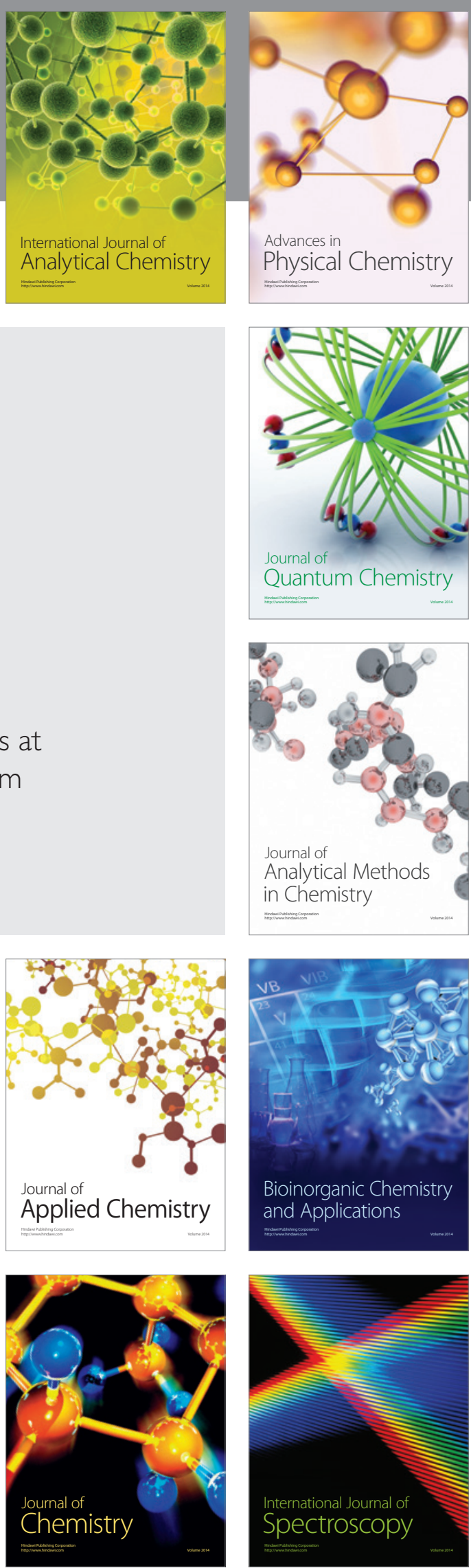